\title{
Water Softening Mechanism and Strength Model for Saturated Carbonaceous Mudstone in Panzhihua Airport, China
}

\author{
Ziwen Wang, ${ }^{1}$ Jifang Du $\mathbb{C},{ }^{2}$ Shuaifeng Wu, ${ }^{1}$ Yingqi Wei, ${ }^{1}$ Jianzhang Xiao, ${ }^{1}$ Wenxi Han, ${ }^{3}$ \\ Di Pan, ${ }^{3}$ and Binbin Zheng ${ }^{2}$ \\ ${ }^{1}$ State Key Laboratory of Simulation and Regulation of Water Cycle in River Basin, \\ China Institute of Water Resources and Hydropower Research, Beijing 100048, China \\ ${ }^{2}$ School of Management Science and Engineering, Shandong Technology and Business University, Yantai 264005, China \\ ${ }^{3}$ College of Environment and Civil Engineering, Chendu University of Technology, Chengdu, China
}

Correspondence should be addressed to Jifang Du; dujfbuaa@buaa.edu.cn

Received 30 May 2020; Revised 4 November 2020; Accepted 19 November 2020; Published 9 December 2020

Academic Editor: Jia-wen Zhou

Copyright ( 2020 Ziwen Wang et al. This is an open access article distributed under the Creative Commons Attribution License, which permits unrestricted use, distribution, and reproduction in any medium, provided the original work is properly cited.

To identify the water softening mechanisms that caused landslides in Panzhihua Airport, China, property and saturation tests of the mudstones extracted from a representative landslide were proposed. In this paper, water saturation tests were carried out on samples of carbonaceous mudstone collected from the east side of the No. 12 landslide at the airport. A number of different analytical techniques and mechanical tests were used to determine changes in chemical composition, mineral assemblages, and mudstone structural characteristics, including shear strength, after the mudstone had been softened. Three kinds of changes caused by water and three mudstone softening stages are proposed. The results show that the water has a significant influence on the properties of the mudstone, so the stability of the mudstone in the watery period is a big threat to the upper structure. A model for water immersion mudstone strength softening is developed. The model incorporates a permeability coefficient, the hydraulic gradient, and time; the model can be used to determine the mudstone's shear strength and internal friction angle. This study provides a reference for the study of rock softened by water immersion.

\section{Introduction}

Mudstone, a soft rock, is widely distributed in southwestern China. Many projects such as dams, airports, and highways are built on mudstone bedrock. The deterioration of soft rock has been and is a long-standing problem for engineering projects all over the world. In the presence of water, many mudstones soften, disintegrate, and swell or shrink and this can lead to many kinds if engineering problems including landslides [1-6].

To solve some of the problems related to water-softened mudstones, researchers have carried out programs that have mainly focused on three aspects: the mudstone's mechanical properties including its strength, mudstones disintegration, and mudstone chemistry. The first aspect concerns mechanical properties [7-11]. The most obvious effect of water softening on mudstone is that the rock's strength decreases.
The mechanical indices compressive strength and shear strength are the main parameters that determine rock strength. After a series of experimental studies, it has been shown that an increase in microporous cracks in the mudstone after the mudstone comes into contact with water leads to a sharp decline in its strength. This indicates that water softening is related to the shape and size of the mudstone's pores [12]. The second aspect is mudstone disintegration $[13,14]$. Some rocks contain expansive clay minerals, and the clay cement will disintegrate when the rock becomes wet. When this occurs, the cement between the clastic particles is destroyed and many microfissures are produced. This destroys the internal structure of the rock and eventually leads to the rock's disintegration. Mudstone disintegration studies are mainly carried out by considering energy storage and transfer using statistics. For example, KINCAL [15] carried out a quantitative analysis of soft rock 
disintegration using the fractal dimension of particle sizes, a fractal dimension equation, and the fractal parameters to establish a model for soft rock disintegration. Miklusova [16] studied the surface area, volume, and particle sizes of debris from disintegrated soft rock, considered the changes in surface energy during disintegration, quantitatively characterized disintegration from the energy perspective, and established a model for energy transfer and dissipation for soft rock disintegration. The third aspect is chemical effects. After they become wet, the hydrophilic minerals in soft rocks exchange ions with and absorb water. Chemical reactions lead to changes in mineral compositions and the rock's structure, and these changes alter the mechanical properties of the rock [17-19].

There are many factors that can affect the softening of mudstone including the rock's clay content [20-23], mineralogy [24], moisture content [25, 27], fabric and texture $[20,21,28,29]$, and porosity [30]. In previous studies, most of the research on mudstone softening by water focused on the analysis of specific factors, but these studies lacked any comprehensive analyses of multiple factors. Moreover, the mudstones from different areas were deposited in different sedimentary environments and had their own special compositions and structural characteristics. Their physical and mechanical properties, the water chemistry at their locations, and the specific water softening mechanism by which they were affected must have been different.

Mudstone is widely distributed in southwestern China where the climate is subtropical monsoonal and humid. From July to October every year, rainfall is very heavy and long periods of heavy rain saturate the ground. Over the past two decades, the global change in climate has led to frequent periods of both extreme rainfall and aridity [31, 32].

In September 2009 landslides occurred at Panzhihua Airport, Sichuan Province, China. These landslides were mainly due to the degradation of mudstone by water saturation; this caused slope instability. This airport is a typical branch airport in mountainous areas, which is the key direction of China's future airport planning and construction. The samples collected in this paper are typical soft rock structures in Southwest China. For this paper, the rock softening mechanisms were studied using a number of techniques including SEM imaging, X-ray fluorescence spectrometry (XRF), liquid ion chromatography, and mechanical property tests. These tests determined the chemical compositions of the rock and water, the minerals present in the rock, any changes in mudstone surface morphology, and the rock's shear strength so that the saturated permeability softening of the mudstone could be investigated. This study can provide a basis for understanding the rock softening engineering problems in this region.

\section{Materials and Testing}

2.1. Basic Physical Properties. The mudstone samples tested are from the east side of the \#12 landslide at Panzhihua Airport. The samples are dark gray or gray-black colored and slippery. Strongly weathered sample is grayish-yellow. Generally, the samples are carbonaceous mudstones. Twelve sets of moisture content, density, and porosity determinations, six sets of uniaxial compression tests, and six sets of direct shear tests were carried out on the natural mudstone samples and on mudstone samples after different water saturation times. The results of the moisture content, density, and porosity tests are listed in Table 1 and Figure 1 . The results show that the porosity varies from $3.7-5.8 \%$ with the change of water content from $1.5-2.62 \%$. The average value of moisture content and porosity are $1.89 \%$ and $4.4 \%$, respectively.

2.2. Chemical Properties and Testing. X-ray fluorescence spectrometry was used to determine the chemical compositions of the rock samples. The results are listed in Table 2. The results show that the major chemical components in the mudstone are $\mathrm{SiO}_{2}, \mathrm{Al}_{2} \mathrm{O}_{3}, \mathrm{CO}_{2}$ (by difference), total $\mathrm{Fe}$ (as $\mathrm{Fe}_{2} \mathrm{O}_{3}$ ), and $\mathrm{CaO}$. The $\mathrm{SiO}_{2}$ content is the largest, at about $60 \%$. The $\mathrm{Al}_{2} \mathrm{O}_{3}$ content is more than $16 \%$, which indicates that aluminum cementation may play a major role in the mudstone. The $\mathrm{CO}_{2}$ content accounts for about $11 \%$, so the rock mudstone contains a carbonaceous component. Generally, mudstones with a $\mathrm{CaO}$ content of more than $10 \%$ have high strength and good weathering resistance but the $\mathrm{CaO}$ content in this mudstone is relatively low, at about $2 \%$, so the $\mathrm{CaO}$ probably makes only an extremely limited contribution to the rock's strength.

Polarizing light microscopy was used to identify the minerals in the samples (Figures 2 and 3 ). In Figure 2, the intensity of the quartz among the non-clay mineral content is significantly more than the other components. The accurate results are listed in Table 3. The clay mineral content is between $75 \%$ and $85 \%$, and the non-clay mineral content is between $15 \%$ and $25 \%$. Therefore, the mudstone's strength mainly is the result of cementation by clay minerals.

Figure 3 shows that the grains that make up the mudstone are only a few microns in diameter. These grains are regular in shape and essentially polygonal and flaky in structure. They form a thin layer of clay in a continuous and nondirectional arrangement, and the grains are in contact face-to-face or edge-to-face. The mineral grains are cemented at their contacts, and this cemented connection is easily damaged by water or an external force. This means that mudstone samples collected from an outcrop are quite soft.

2.3. Mechanical Properties. The samples of the mudstone have been processed the uniaxial compression and the direct shear tests in the laboratory, and the test details are shown in Figure 4. The experimental results from the uniaxial compression and the direct shear tests on the mudstone specimens are presented in Tables 4 and 5 . The compression tests show that the uniaxial compressive strength of the natural mudstone from the study area is not high; the average compressive strength is only $10.51 \mathrm{MPa}$. 
TABle 1: Average mudstone sample natural and dry density, natural moisture content, and porosity.

\begin{tabular}{lcccc}
\hline Naming under microscope & Natural density $\left(\mathrm{g} / \mathrm{cm}^{3}\right)$ & Dry density $\left(\mathrm{g} / \mathrm{cm}^{3}\right)$ & Natural moisture content $(\%)$ & Porosity $(\%)$ \\
\hline Mudstone & 2.42 & 2.39 & 1.89 & 4.40
\end{tabular}

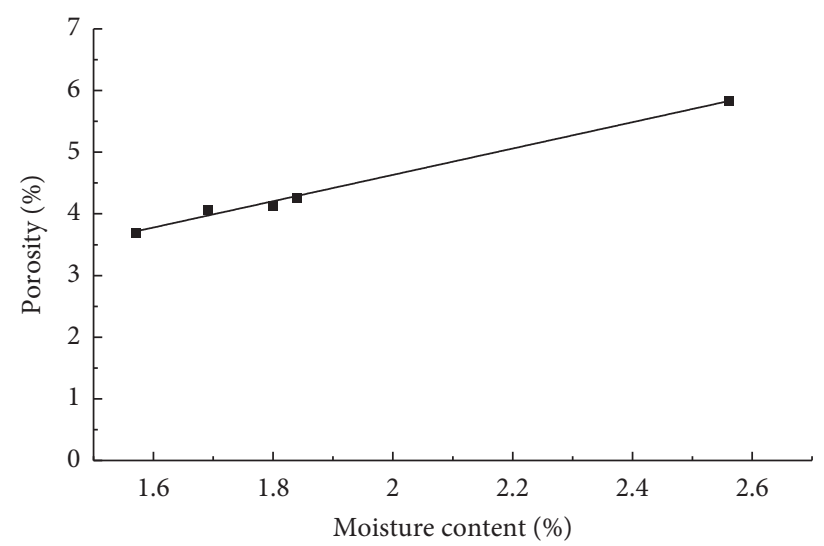

Figure 1: Water content and porosity of natural (unaltered) mudstone samples.

TABLE 2: Average mudstone whole-rock major element chemical analysis.

\begin{tabular}{lccccc}
\hline Naming under microscope & \multicolumn{4}{c}{ Main chemical composition and content (\%) } \\
\hline \multirow{3}{*}{ Mudstone } & $\mathrm{SiO}_{2}$ & $\mathrm{Al}_{2} \mathrm{O}_{3}$ & $\mathrm{CO}_{2}$ & $\mathrm{Fe}_{2} \mathrm{O}_{3}$ & $\mathrm{~K}_{2} \mathrm{O}$ \\
& 59.53 & 16.46 & 10.92 & 3.87 & 3.25 \\
& $\mathrm{MgO}$ & $\mathrm{CaO}$ & $\mathrm{Na}_{2} \mathrm{O}$ & Others & Silicon/aluminium ratios \\
& 2.34 & 1.96 & 0.69 & 0.98 & 5.23 \\
\hline
\end{tabular}

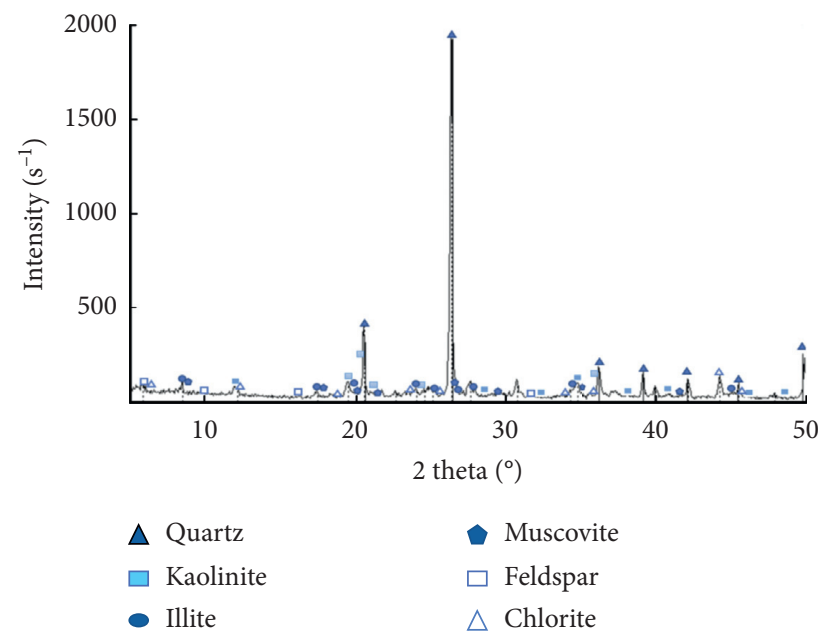

Figure 2: X-ray diffraction pattern from a typical mudstone sample.

The shear strength indices of the mudstone layer groups in the study area are $c=1.96 \mathrm{MPa}$ and $\operatorname{tg} \varphi=0.6442$ $\left(\varphi=32.79^{\circ}\right)$. The normal stress-shear strength curve for mudstone, $\sigma-\tau$, is shown in Figure 5. The results show that the original strength of the mudstone is relatively high compared with the normal samples. Therefore, it is essential to understand the reason of instability and the process of water softening. 


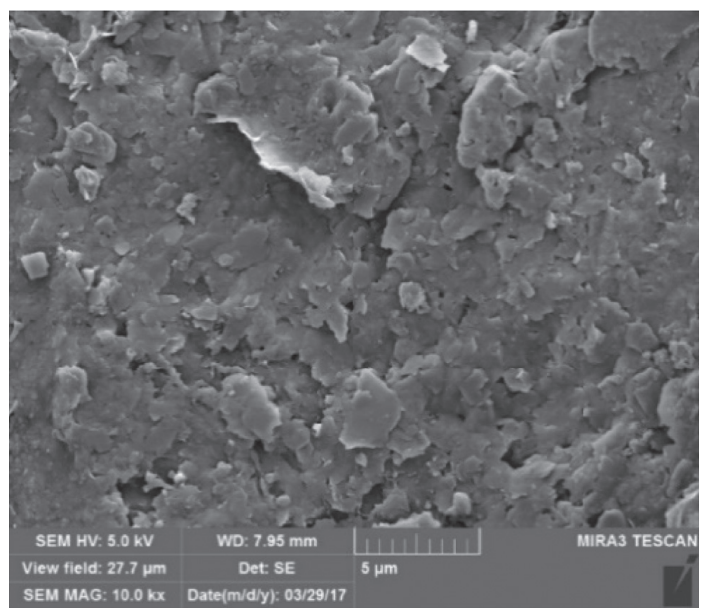

Figure 3: SEM micrograph of a mudstone sample $(10,000 \times)$.

TABLE 3: Mineral abundances in three mudstone samples (\%).

\begin{tabular}{|c|c|c|c|c|c|}
\hline \multirow{2}{*}{ Serial number } & \multicolumn{5}{|c|}{ Composition and content of fabric minerals (\%) } \\
\hline & Clay mineral & Quartz & Feldspar & Carbonaceous & Others \\
\hline 1 & 80 & $5-10$ & $3-5$ & $2-3$ & 5 \\
\hline 2 & $75-80$ & $5-10$ & $2-3$ & 5 & 5 \\
\hline 3 & 85 & $5-10$ & $3-5$ & $2-3$ & 2 \\
\hline
\end{tabular}

\section{Softening Tests}

To study the softening and strength changes in the carbonaceous mudstones, the changes in microphysical, chemical, and macromechanical properties of the samples before and after water saturation were investigated. The testing scheme divided the samples into five groups. The groups were saturated with water for $5,10,20,30$, and $60 \mathrm{~d}$ periods, and the samples' microstructure, mineral composition, and the chemical compositions of the rocks and the immersion water were analyzed before and after saturation. Compression and direct shear tests were also carried out to analyze softening.

\section{Softening Analysis}

4.1. Chemical, Mineralogic, and Morphologic Changes during Softening. The chemical composition of the mudstone, the chemical composition of water, and the microstructure of the mudstone were analyzed to investigate the softening mechanisms.

4.1.1. Changes in Mudstone Chemical Composition. X-ray fluorescence spectrometry was used to analyze the chemical compositions of the mudstones. For each analysis, a dried sample was ground to 200 mesh and lowpressure polyethylene powder was used to coat the bottom. A tablet press was used to prepare samples with an inner diameter of $32 \mathrm{~mm}$ and an outer diameter of $40 \mathrm{~mm}$ for XRF analysis. The test results and the changes in $\mathrm{SiO}_{2}, \mathrm{Al}_{2} \mathrm{O}_{3}$, the $\mathrm{Si} / \mathrm{Al}$ ratio, and the active oxides $\left(\mathrm{Na}_{2} \mathrm{O}\right.$ and $\mathrm{K}_{2} \mathrm{O}$ ) after the $60 \mathrm{~d}$ immersion period are listed in Table 6.

Over the $60 \mathrm{~d}$ immersion period, the $\mathrm{SiO}_{2}$ and $\mathrm{Al}_{2} \mathrm{O}_{3}$ concentrations are very stable but, as can be seen from the analyses in Table 6, the $\mathrm{Fe}_{2} \mathrm{O}_{3}$ decreases during the saturation period. This decrease in $\mathrm{Fe}_{2} \mathrm{O}_{3}$ should be compared with the changes in ion abundances in the soaking solution. The content of $\mathrm{CO}_{2}$ in the mudstone remains essentially unchanged but the potassium, sodium, calcium, and magnesium oxide contents all decrease. As shown in Table 6, the percentage by which $\mathrm{K}_{2} \mathrm{O}$ and $\mathrm{Na}_{2} \mathrm{O}$ decrease in the $60 \mathrm{~d}$ period is relatively large although the abundances of those two elements stabilize somewhat after about $30 \mathrm{~d}$ of water saturation. The silicon aluminum ratio is between 4.95 and 5.28 and does not change significantly over $60 \mathrm{~d}$.

4.1.2. Changes in Soaking Solution Chemical Composition. Inductively coupled plasma atomic emission spectroscopy and ion chromatography were used to determine the abundances of several ions in the mudstone soaking solutions used in the five immersion experiments. The changes in the solution's ion concentrations were analyzed. The raw soaking solution was ultrapure water, and it contained no detectable ions-the initial content of both anions and 


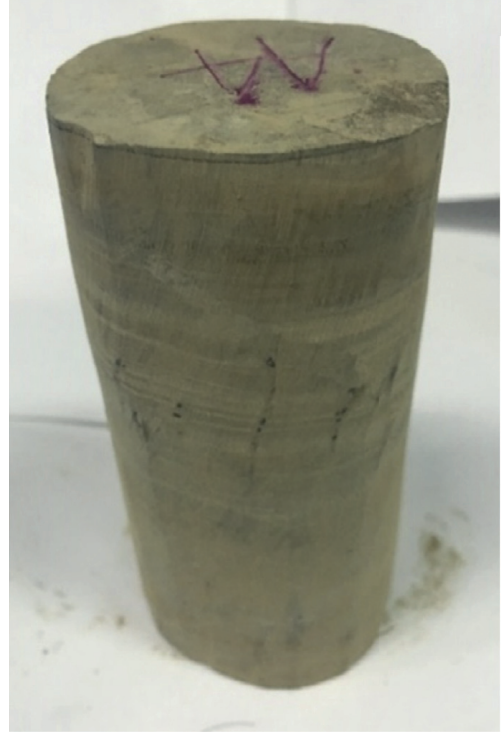

(a)

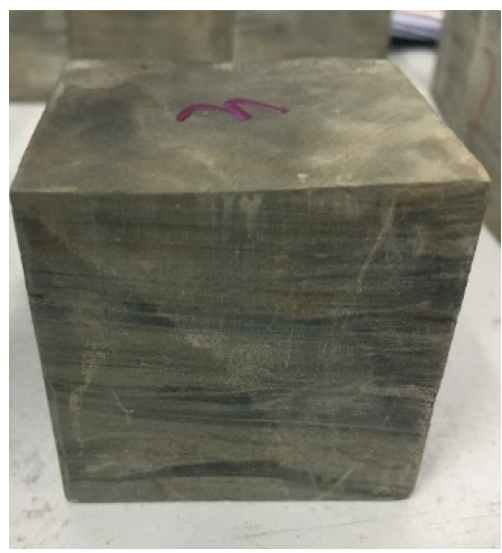

(c)

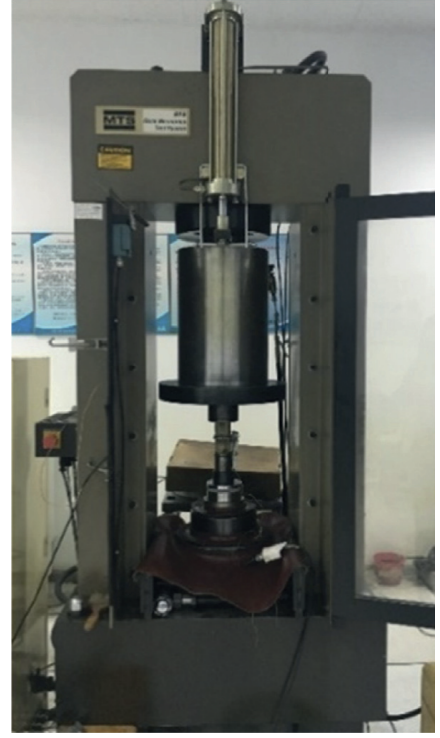

(b)

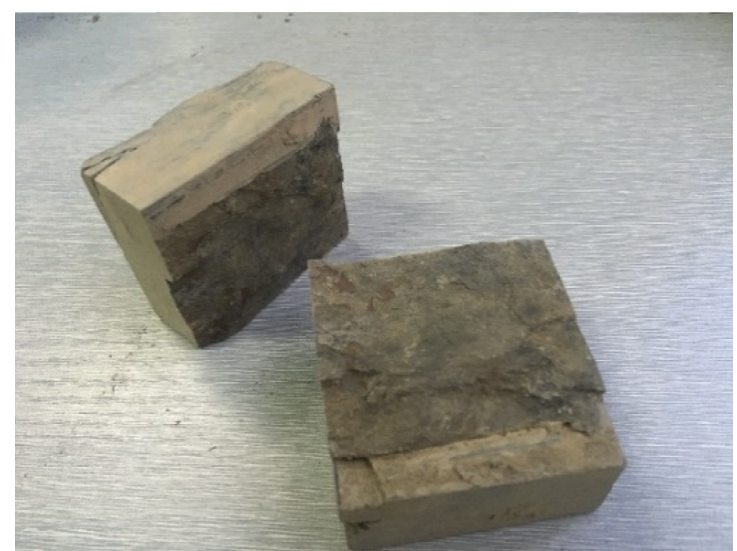

(d)

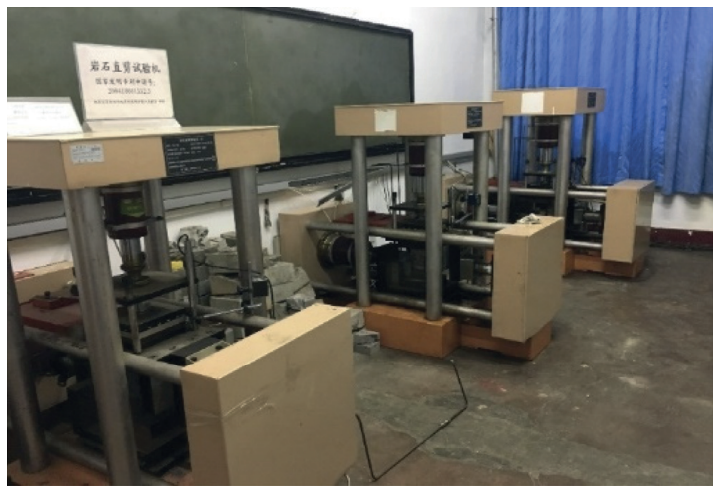

(e)

Figure 4: The mechanical tests of the samples. (a) Uniaxial compressive strength specimens. (b) MTS integrated testing system for rock mechanics. (c) Direct shear specimen. (d) Direct shear specimen of bedding plane crack. (e) Rock direct shear testing machine.

TABLE 4: Results of the uniaxial compression test on three mudstone samples.

\begin{tabular}{lccc}
\hline Serial number & Sectional area of the sample $\left(\mathrm{cm}^{2}\right)$ & Uniaxial compressive strength $(\mathrm{MPa})$ & Average value $(\mathrm{MPa})$ \\
\hline 1 & 19.63 & 10.65 & 10.51 \\
2 & 19.94 & 9.72 & 11.16 \\
3 & 19.23 & & \\
\hline
\end{tabular}


TABLE 5: Results of shear strength tests on five mudstone samples.

\begin{tabular}{lcccc}
\hline Serial number & Shear area $\left(\mathrm{cm}^{2}\right)$ & Normal stress $\sigma(\mathrm{MPa})$ & Shear stress $\tau(\mathrm{MPa})$ & Shear strength \\
\hline 1 & 24.56 & 1.20 & 2.66 & $c=1.96 \mathrm{MPa}$ \\
2 & 24.52 & 2.40 & 3.80 & \\
3 & 23.73 & 3.60 & 4.13 & $\operatorname{tg} \varphi=0.6442\left(\varphi=32.79^{\circ}\right)$ \\
4 & 24.35 & 4.80 & 4.75 & 6.05 \\
5 & 23.06 & 6.00 & & \\
\hline
\end{tabular}

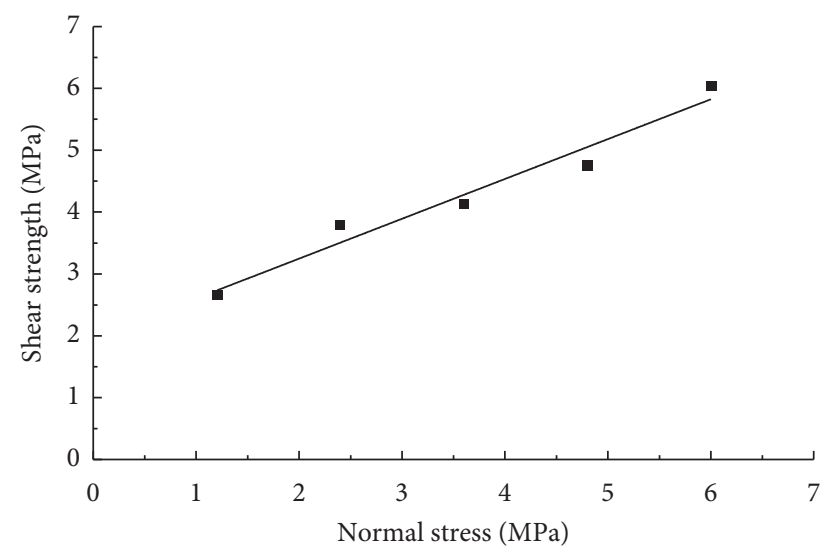

Figure 5: Normal stress vs. shear strength for the five mudstone samples in Table 5.

TABLE 6: Whole-rock major element analyses of mudstone samples after different saturation times.

\begin{tabular}{|c|c|c|c|c|c|c|c|c|c|c|c|}
\hline \multirow{2}{*}{$\begin{array}{l}\text { Saturation time } \\
\text { (d) }\end{array}$} & \multicolumn{11}{|c|}{ Main chemical composition and content (\%) } \\
\hline & $\mathrm{SiO}_{2}$ & $\mathrm{Al}_{2} \mathrm{O}_{3}$ & $\mathrm{CO}_{2}$ & $\mathrm{Fe}_{2} \mathrm{O}_{3}$ & $\mathrm{~K}_{2} \mathrm{O}$ & $\mathrm{MgO}$ & $\mathrm{CaO}$ & $\mathrm{Na}_{2} \mathrm{O}$ & Others & Silicon/aluminium ratios & Active oxide \\
\hline 0 & 59.53 & 16.46 & 10.92 & 4.46 & 3.25 & 2.34 & 1.73 & 0.66 & 0.65 & 5.23 & 7.98 \\
\hline 5 & 58.83 & 17.30 & 11.04 & 3.88 & 3.05 & 2.32 & 1.67 & 0.64 & 1.27 & 5.05 & 7.68 \\
\hline 10 & 59.77 & 16.93 & 10.10 & 4.10 & 3.00 & 2.23 & 1.72 & 0.60 & 1.55 & 5.19 & 7.55 \\
\hline 20 & 59.14 & 17.73 & 11.18 & 4.00 & 2.67 & 2.33 & 1.68 & 0.55 & 0.72 & 4.95 & 7.23 \\
\hline 30 & 59.86 & 16.84 & 11.37 & 3.73 & 2.60 & 2.24 & 1.55 & 0.50 & 1.31 & 5.28 & 6.89 \\
\hline 60 & 59.00 & 17.38 & 11.04 & 3.47 & 2.40 & 2.20 & 1.41 & 0.49 & 2.61 & 5.11 & 6.50 \\
\hline Change in 60 days (\%) & -0.9 & 5.6 & 1.1 & -22.2 & -26.2 & -6.0 & -18.5 & -25.8 & & -2.29 & -18.55 \\
\hline
\end{tabular}

TABLE 7: Ion concentrations and total ion abundances in the mudstone soaking solutions from the five immersion experiments.

\begin{tabular}{lccccccccccccccc}
\hline Saturation time $(\mathrm{d})$ & $\mathrm{PH}$ & $\mathrm{Na}+$ & $\mathrm{K}+$ & $\mathrm{Ca}^{2+}$ & $\mathrm{Mg}^{2+}$ & $\mathrm{Si}^{4+}$ & $\mathrm{Al}^{3+}$ & $\mathrm{Fe}^{3+}$ & $\mathrm{F}-$ & $\mathrm{Cl}-$ & $\mathrm{NO}^{3-}$ & $\mathrm{SO}_{4}^{2-}$ & Active cation & Total cation & Total anions \\
\hline 0 & 7.00 & 0.00 & 0.00 & 0.00 & 0.00 & 0.00 & 0.00 & 0.00 & 0.00 & 0.00 & 0.00 & 0.00 & 0.00 & 0.00 & 0.00 \\
5 & 6.87 & 0.59 & 1.33 & 3.79 & 1.34 & 0.14 & 0.03 & 0.07 & 0.05 & 0.64 & 2.20 & 0.83 & 7.05 & 7.29 \\
10 & 6.62 & 1.70 & 2.57 & 9.31 & 4.17 & 0.11 & 0.02 & 0.01 & 0.17 & 1.91 & 1.63 & 1.16 & 17.74 & 17.88 \\
20 & 7.10 & 2.26 & 2.91 & 16.24 & 7.44 & 0.23 & 0.02 & 0.01 & 0.18 & 2.32 & 1.94 & 1.39 & 28.85 & 29.11 \\
30 & 7.55 & 2.39 & 2.75 & 17.11 & 7.93 & 0.22 & 0.03 & 0.01 & 0.28 & 2.82 & 3.53 & 1.89 & 30.17 & 30.43 & 8.84 \\
60 & & 3.23 & 3.50 & 27.91 & 10.72 & 0.23 & 0.05 & 0.02 & 0.35 & 2.52 & 3.67 & 1.74 & 45.37 & 45.66 \\
\hline
\end{tabular}

cations in the solution was zero. The results of the soaking solution ion analyses and the changes in $\mathrm{Ca}^{2+}, \mathrm{SO}_{4}^{2--}$, total cations, and total anions are listed in Table 7.
Over the course of the immersion tests, the concentration of $\mathrm{Ca}^{2+}$ ions shows a continuous rising trend; the concentration of $\mathrm{Ca}^{2+}$ ions increases by the largest 
percentage among all the ions in solution. The concentration of $\mathrm{Ca}^{2+}$ ions increases notably during the 30-60 d water saturation period. The concentration of $\mathrm{Mg}^{2+}$ in the $0-20 \mathrm{~d}$ period of water saturation also shows a rising trend. This growth trend slows after $20 \mathrm{~d}$, and the $\mathrm{Mg}^{2+}$ concentration becomes stable after $30 \mathrm{~d}$. This indicates that mudstone's $\mathrm{Mg}^{2+}$ is precipitated and dissolved very little in that period. The concentrations of the $\mathrm{K}^{+}$and $\mathrm{Na}^{+}$ions begin to stabilize after $0-10 \mathrm{~d}$ of water saturation, and the growth trend for these ions slows after $10 \mathrm{~d}$ and becomes generally stable after $30 \mathrm{~d}$. The $\mathrm{Si}^{4+}, \mathrm{Al}^{3+}$, and $\mathrm{Fe}^{3+}$ ions mainly come from relatively insoluble minerals and these minerals, being generally stable, contribute very few ions to the immersion solution. The concentrations of these ions did not change significantly although the total cation concentration shows an upward trend during the $0-60 \mathrm{~d}$ period of water saturation.

During the water saturation tests, the concentration of $\mathrm{NO}_{3}{ }^{-}$ions first increased, then decreased, but then increased again. Overall, the $\mathrm{NO}_{3}{ }^{-}$concentration increased considerably, and it apparently increased continuously over the 20-60 d period. After $30 \mathrm{~d}$ of water saturation, the $\mathrm{NO}_{3}{ }^{-}$ concentration tended to be stable. At $60 \mathrm{~d}$, its concentration was the highest of any anion in the solution. The $\mathrm{SO}_{4}^{2-}, \mathrm{Cl}^{-}$, and $\mathrm{F}^{-}$anions showed continuous growth in the $0-30 \mathrm{~d}$ period, and their growth rate was rapid from $0 \mathrm{~d}$ to $10 \mathrm{~d}$ but significantly reduced from 20 to $30 \mathrm{~d}$. After about $30 \mathrm{~d}$ of water saturation, the sulfur, chlorine, and fluorine ion growth rates tended to stabilize. The $\mathrm{F}^{-}$growth rate was the slowest, and the total $\mathrm{F}^{-}$ion concentration was low. The total anions showed a continuous growth trend in the $0-30 \mathrm{~d}$ period and tended to be stable after $30 \mathrm{~d}$ of water saturation. The water was weakly acidic in the $5 \mathrm{~d}$ and $10 \mathrm{~d}$ soaking solutions, but the $\mathrm{pH}$ changed to weak alkaline in the $20 \mathrm{~d}$ and $30 \mathrm{~d}$ solutions.

4.1.3. Changes in Mineralogy. X-ray diffraction analyses were carried out on unaltered mudstone samples and on samples after $30 \mathrm{~d}$ and $60 \mathrm{~d}$ of water saturation. Figure 6 shows X-ray diffraction patterns from an unaltered mudstone along with patterns for $30 \mathrm{~d}$ and $60 \mathrm{~d}$ water saturated mudstones and a pattern from natural state for comparison.

It can be seen that the three characteristic peaks of muscovite and feldspar are obviously weakened with the increase in water saturation time, and the content is reduced to a certain extent. After $30 \mathrm{~d}$ of water saturation, the three characteristic kaolinite peaks increased slightly and a small amount of newly formed kaolinite was observed. After $30-60 \mathrm{~d}$ of water saturation, the kaolinite peaks weakened and the content decreased.

4.1.4. Changes in Mudstone Surface Morphology. Changes in mudstone surface morphology after water saturation were observed and documented by SEM imaging. An image of the surface of a mudstone sample after $60 \mathrm{~d}$ of water saturation is shown at two different magnifications in Figure 7.

After $60 \mathrm{~d}$ of water saturation, almost all the coarse grains and aggregates that constituted much of the mudstone's cement have been removed. The mudstone components that remain are loosely stacked together forming stacked structures of flaky grains. The rock's structure has changed from the original compact state to a disordered state, and the number of microfractures around the pores has increased considerably.

4.2. Mudstone Softening. According to the analysis presented in the previous sections, the water softening of mudstone is the result of the combined influence of physical, chemical, and mechanical processes. The effects of these processes can be classified as chemical erosion, hydraulic wedge splitting, and hydrolysis. These three agents are discussed below.

Chemical erosion: most of the salts in the minerals that compose the mudstone are soluble salts. These dissolve into the soaking solution during water saturation. The ionic concentration of the initially pure (zero ions) immersion water increases after the saturation tests, showing that mineral dissolution must have occurred.

Hydraulic wedge splitting: water molecules infiltrate into the lattice structure of mudstone minerals along microcracks. This squeezing action is called wedge splitting, and it shows that microcrack development increases as the water saturation time increases.

Hydrolysis: the chemical reactions between the minerals in the mudstone and the soaking solution produce new salt minerals. This is shown by the changes in the X-ray diffraction patterns and the changes in the soaking solution's $\mathrm{pH}$.

The chemical and microstructural changes in the mudstone during water saturation, the softening phase, can be divided into three stages:

(1) The initial softening stage $(0-10 \mathrm{~d})$ : in this stage, the soluble salts are gradually dissolved from the mudstone and the ionic strength of the soaking solution increases; pores and fractures begin to develop in the mudstone and the mudstone's structure begins to break down. This stage is predominantly one of chemical erosion.

(2) The advanced softening stage (10-30 d): the soluble salt in mudstone gradually decrease, the ion concentration in the soaking solution continues to rise, and the softening effect is stronger than the previous stage.

(3) The stable softening stage (more than $30 \mathrm{~d}$ ): the ion exchange tends towards equilibrium, and the effect of chemical erosion is weakening. The pores increase in size, and wedge splitting is more pronounced. 


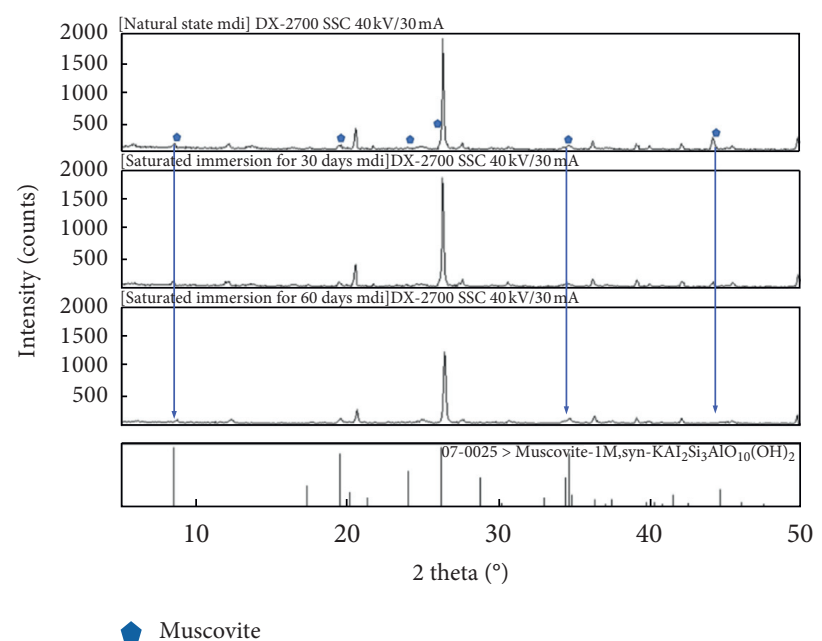

FIGURE 6: Mineral composition comparison of mudstone with XRD.
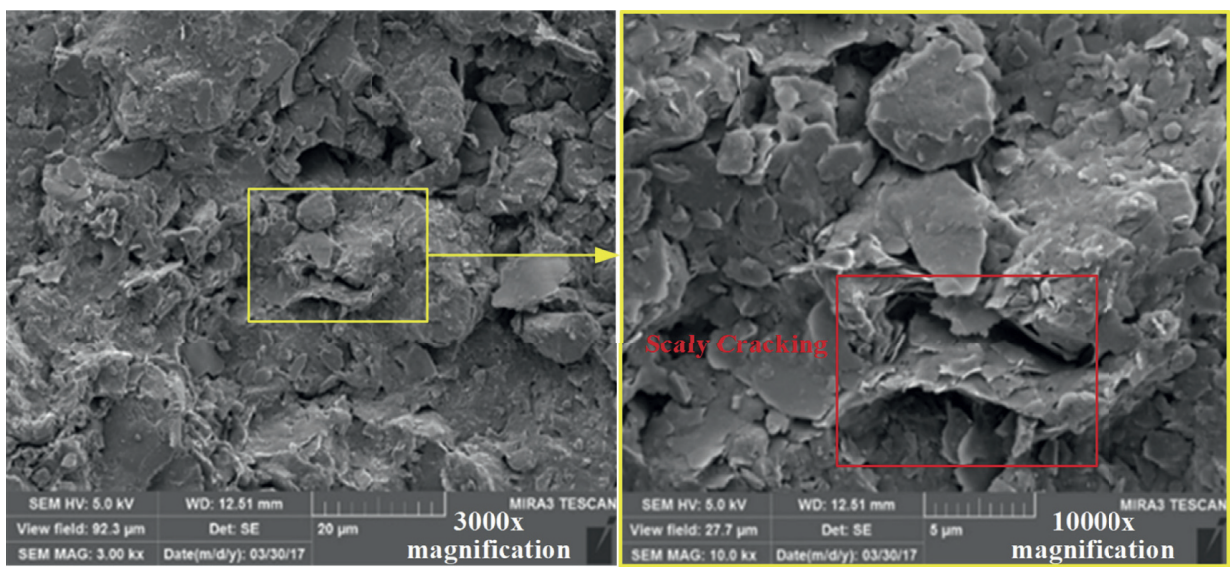

FIGURE 7: Scanning electron microscope images of the surface of a mudstone sample after 60 days of water saturation. The image on the right shows the area inside the yellow box on the image on the left at higher magnification.

\section{Saturated Mudstone Softening Model}

5.1. Mechanical Properties after Different Saturation Times. Direct shear tests were conducted after different mudstone saturation times. The $\sigma-\tau$ curves from those tests are presented in Figure 8. The shear strength index $c$ and the internal friction angle $\varphi$ for those mudstones were then calculated; those values and the change of mudstone strength after different saturation times are listed in Table 8. The results show that the mudstone's shear strength tends to be stable after $30 \mathrm{~d}$ of water saturation but the cohesion and internal friction angle decrease by $26.53 \%$ and $42.19 \%$, respectively, after $60 \mathrm{~d}$ of saturation.

5.2. Strength Softening Model for Saturated Mudstone. Analysis of the test results revealed that after water immersion, mudstone softening is due to the combined effects of hydrolysis, wedge splitting, and chemical weathering. The softening results in a reduction in the mudstone's strength.
This conclusion is the basis for a soft rock strength-softening model that postulates that the rock is softened under the influence of a permeability coefficient $K$ and a hydraulic gradient $I$ over time $t$. This model can be expressed as follows:

$$
Q=f\left(k, i, t, Q_{0}\right)
$$

where $K$ is the permeability coefficient for soft rock; $I$ is the hydraulic gradient; $t$ is the permeability time; and $Q_{0}$ is the initial strength index value, which can be either cohesion $c$ or internal friction angle $\varphi$.

According to the water saturation time-strength test results, the longer the water saturation time, the more the strength is degraded. After analysis, we think that the reduction of strength is a reduction under the combined action of these factors, and a reduction function with a factor of $\Delta$ is proposed. The factor $\Delta$, a function of time, permeability coefficient, hydraulic gradient, and pattern thickness, is recognized. This factor is used as the independent variable in 


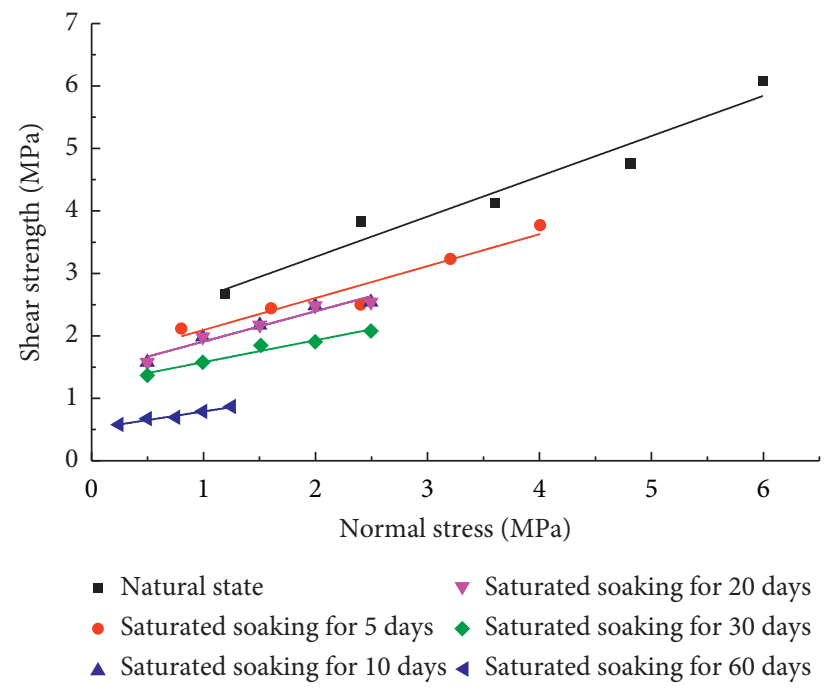

FIGURE 8: Shear strength vs. normal stress for mudstones after being saturated for different lengths of time.

Table 8: Shear strength, internal friction angle, and other indices for mudstone samples after different saturation soaking times.

\begin{tabular}{|c|c|c|c|c|c|c|}
\hline \multirow{2}{*}{ Index } & \multicolumn{6}{|c|}{ Saturation soaking time $(\mathrm{d})$} \\
\hline & 0 & 5 & 10 & 20 & 30 & 60 \\
\hline $\mathrm{C}(\mathrm{MPa})$ & 1.96 & 1.58 & 1.43 & 1.25 & 0.63 & 0.52 \\
\hline$\varphi\left({ }^{\circ}\right)$ & 32.79 & 27.02 & 25.64 & 22.78 & 16.70 & 15.11 \\
\hline Attenuation rate of the cohesion (\%) & 100 & 80.61 & 72.96 & 63.78 & 32.14 & 26.53 \\
\hline Attenuation rate of the internal friction angle (\%) & 100 & 79.69 & 75.00 & 65.63 & 46.88 & 42.19 \\
\hline Uniaxial compressive strength $(\mathrm{MPa})$ & 10.51 & 7.16 & 4.35 & 3.39 & 1.97 & 0.94 \\
\hline Attenuation rate of the uniaxial compressive strength (\%) & 100 & 68.13 & 41.39 & 32.25 & 18.74 & 8.94 \\
\hline Moisture content $(\%)$ & 1.89 & 3.36 & 3.69 & 4.26 & 4.5 & 4.65 \\
\hline Porosity (\%) & 4.4 & 7.35 & 8.36 & 9.74 & 10.68 & 10.9 \\
\hline
\end{tabular}

the strength reduction model to represent the water softening of soft rock. A definite integral model is used to construct the time-dependent variables, and the longer the time, the greater the reduction factor, as shown in the following equation:

$$
\Delta=\int_{0}^{t} k \cdot i \cdot t d t
$$

The factor $\Delta$ is called the intermediate characterization quantity.

Taking the results in Table 8 as an example, the permeability coefficient $K$ for mudstone is $1.49 \times 10^{-14} \mathrm{~m} / \mathrm{s}$ and the hydraulic gradient $I=1$ for shallow immersion. The corresponding strength reduction relationship between the infiltration amount and $\varphi$ at 5, 10, 20, 30, and $60 \mathrm{~d}$ immersion times is shown in Figure 9.

Based on the relationship between the intermediate characterization and the friction angle attenuation, a strength model for the internal friction angle was established. That model is represented by the following equation:

$$
\varphi=\left\{0.8366-0.3792 \cdot\left[1-\exp \left(\frac{-\int_{0}^{t} k \cdot i \cdot t d t}{0.0353}\right)\right]\right\} \cdot \varphi_{0}
$$

where $\varphi_{0}$ is the initial internal friction angle from the direct shear test.

Then, the strength-saturation time model is established by expanding equation (3) to generate the following equation:

$$
Q=\left\{\alpha-\beta \cdot\left[1-\exp \left(\frac{-\int_{0}^{t} k \cdot i \cdot t d t}{\gamma}\right)\right]\right\} \cdot Q_{0},
$$

where $\alpha, \beta$, and $\gamma$ are undetermined coefficients.

The strength indices calculated from this strengthsoftening model are compared with the test values. The results are listed in Table 9.

The two groups of values listed in Table 9 were plotted, and the graph is shown in Figure 10. 


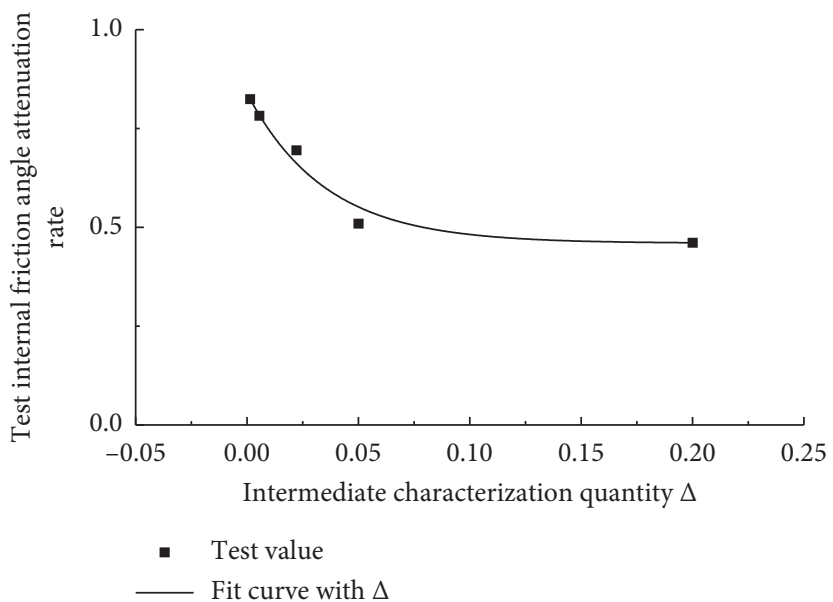

Figure 9: Relationship between intermediate characterization $(\Delta)$ and the internal friction angle attenuation rate (from Table 8).

TABLE 9: Comparison of the strength index values $c$ and $\varphi$ calculated from the model with the values derived from the direct shear tests.

\begin{tabular}{|c|c|c|c|c|c|}
\hline & Saturation soaking time $(\mathrm{d})$ & Coefficient & Calculated value & Test value & Error \\
\hline \multirow{5}{*}{$\mathrm{C}(\mathrm{MPa})$} & 5 & & 1.58 & 1.58 & 0.00 \\
\hline & 10 & $\alpha=0.8307 \beta=$ & 1.45 & 1.43 & -0.02 \\
\hline & 20 & $0.5664 \gamma=$ & 1.06 & 1.25 & 0.19 \\
\hline & 30 & 0.0312 & 0.74 & 0.63 & -0.11 \\
\hline & 60 & & 0.52 & 0.52 & 0.00 \\
\hline \multirow{5}{*}{$\varphi\left({ }^{\circ}\right)$} & 5 & & 26.69 & 27.02 & 0.33 \\
\hline & 10 & $\alpha=0.8366 \beta=$ & 25.36 & 25.64 & 0.28 \\
\hline & 20 & $0.3792 \gamma=$ & 21.36 & 22.78 & 1.42 \\
\hline & 30 & 0.0353 & 17.76 & 16.70 & -1.06 \\
\hline & 60 & & 14.78 & 15.11 & 0.33 \\
\hline
\end{tabular}

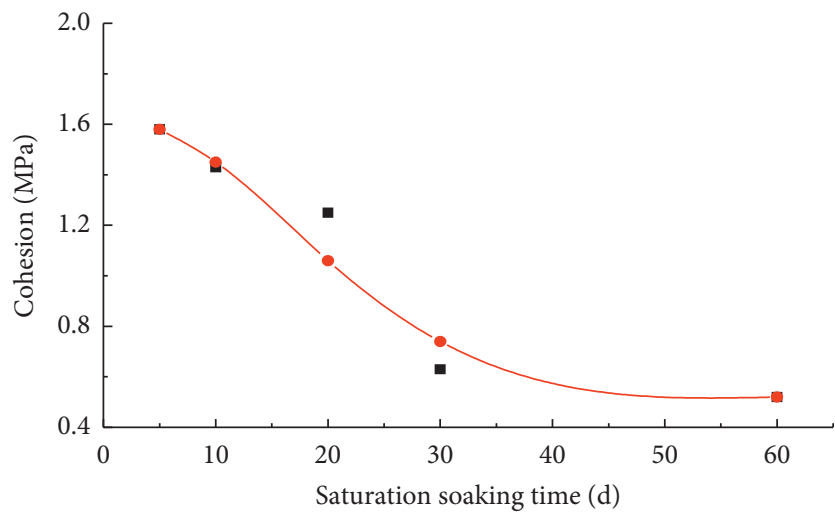

- Test value

- Calculation value by the model

(a)

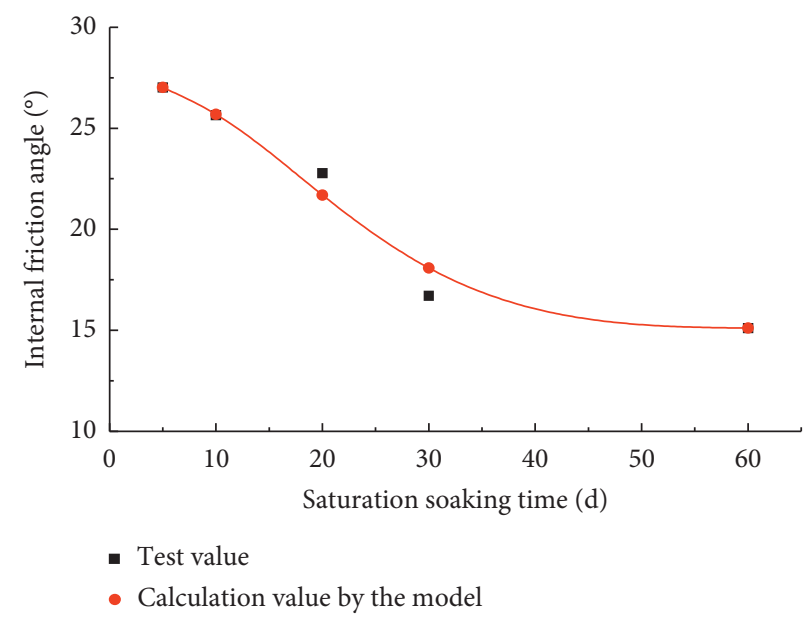

(b)

FIGURE 10: Graphs comparing direct shear test values and calculated values for (a) cohesion $c$ and (b) internal friction angle $\varphi$.

\section{Conclusions}

Saturation tests on mudstone from the east side of the \#12 Panzhihua Airport landslide (Sichuan Province, China) were carried out. Physical and geochemical tests and analyses on the softened rock and fluids from those saturation tests are proposed. The results show that after water saturation, the mudstone's strength decreases but a number of different physical and mechanical properties tend to stabilize after $30 \mathrm{~d}$ of water immersion. After $60 \mathrm{~d}$ of water immersion, the cohesion $c$ and internal friction angle $\varphi$ decay to $26.53 \%$ and $42.19 \%$, respectively, of the $c$ and $\varphi$ values for unaltered 
mudstone. The mudstone's original water content and porosity increase by factors of 2.46 and 2.48 , respectively, after $60 \mathrm{~d}$. The mudstone softening results from physical, chemical, and mechanical processes that can be classified as chemical undercutting, hydraulic wedge splitting, and hydrolysis. The softening can be divided into three stages: the initial softening stage $(0-10 \mathrm{~d})$, the advanced softening stage $(10-30 \mathrm{~d})$, and the stable softening stage (more than $30 \mathrm{~d}$ ).

Therefore, the saturation time has a significant influence on the properties of the stability of mudstone which also been a threaten to the upper structure stability. To quantification the water softening process, a mudstone strengthsoftening model is proposed. The model incorporates a permeability coefficient $K$, a hydraulic gradient $I$, and time $t$ and can be used to determine both the mudstone's the shear strength $c$ and internal friction angle $\varphi$.

\section{Data Availability}

The data used to support the findings of this study are available from the corresponding author upon request.

\section{Conflicts of Interest}

The authors declare that they have no conflicts of interest regarding the publication of this paper.

\section{Acknowledgments}

This research was supported by the Independent Research Topics from the State Key Laboratory of Simulation and Regulation of the Water Cycle in River Basins (grant no. SKL2020TS05), IWHR Research and Development Support Program (grant no. GE0145B412019), and National Natural Science Foundation of China (grant no. 51804178). The authors thank David Frishman, PhD, from Liwen Bianji, Edanz Editing China, for editing the English text of a draft of this manuscript.

\section{References}

[1] W.-C. Haneberg and A. Gökce, Rapid Water-Level Fluctuations in a Thin Colluvium Landslide West of Cincinnati, US Government Printing Office, Cincinnati, OH, USA, 1994.

[2] R. L. Baum, Contribution of Artesian Water to Progressive Failure of the Upper Part of the Delhi Pike Landslide Complex, US Government Printing Office, Cincinnati, OH, USA, 1994.

[3] J. Peng, Z. Fan, D. Wu et al., "Heavy rainfall triggered loessmudstone landslide and subsequent debris flow in Tianshui, China," Engineering Geology, vol. 186, pp. 79-90, 2015.

[4] Z. Zhang, T. Wang, S. Wu, H. Tang, and C. Liang, "The role of seismic triggering in a deepseated mudstone landslide, China: historical reconstruction and mechanism analysis," Engineering Geology, vol. 226, pp. 122-135, 2015.

[5] R. J. Day-Stirrat, P. B. Flemings, Y. You, and B. A. van der Pluijm, "Modification of mudstone fabric and pore structure as a result of slope failure: ursa Basin, Gulf of Mexico," Marine Geology, vol. 341, pp. 58-67, 2013.

[6] M. Quinta-Ferreira, P. S. Andrade, L. Lemos, and A. Saraiva, "Cut slopes failures on the Triassic beds in Coimbra,
Portugal," Bulletin of Engineering Geology and the Environment, vol. 72, no. 3-4, pp. 383-396, 2013.

[7] C. Ma, T. Zhang, and W. Yao, "An assessment of the osmotic pressure effect on the creep properties of silty mudstone," Soil Mechanics and Foundation Engineering, vol. 56, pp. 314-320, 2019.

[8] M. Kikumoto, A. D. Putra, and T. Fukuda, "Slaking and deformation behaviour," Géotechnique, vol. 66, no. 9, pp. 771-785, 2016.

[9] K. Sharma, T. Kyokawa, and K. Hiroyuki, "Effect of slaking on direct shear behaviour of crushed mudstones," Soils and Foundations, vol. 57, no. 2, pp. 288-300, 2017.

[10] J. Hadizadeh and R. D. Law, "Water-weakening of sandstone and quartzite deformed at various stress and strain rates," International Journal of Rock Mechanics and Mining Sciences \& Geomechanics Abstracts, vol. 28, no. 5, pp. 431-439, 1991.

[11] C. H. Yang, H. J. Mao, X. C. Wang, X. H. Li, and J. W. Chen, "Study on variation of microstructure and mechanical properties of water-weakening slates," Rock \& Soil Mechanics, vol. 27, no. 12, pp. 2090-2098, 2006, in Chinese.

[12] L. Zeng, J. Liu, Q. F. Gao, and H. Bian, "Evolution characteristics of the cracks in the completely disintegrated carbonaceous mudstone subjected to cyclic wetting and drying," Advances in Civil Engineering, vol. 201910 pages, 2019.

[13] X. Liu, Y. Li, S. Li, and Y. Zhou, "Research on the disintegration characteristics of carbonaceous mudstone and properties of modified materials," Advances in Civil Engineering, vol. 201910 pages, 2019.

[14] L. Zeng, Z. N. Shi, and H. Y. Fu, "Road performance of preliminary disintegration of carbon mudstone and mechanical characteristics based on CT-Triaxial test," Journal of Central South University (Science and Technology), vol. 47, pp. 2030-2036, 2016.

[15] C. Kincal, M. Y. Koca, G. Ozden, and N. Demirbasa, "Fractal parameter approach on weathering grade determination of Çeşme (Izmir, Turkey) tuffs," Bulletin of Engineering Geology and the Environment, vol. 69, pp. 617-629, 2010.

[16] V. Miklusova and L. Ivanicova, "Energetic approach to the evaluation of rock disintegration process," Acta Montanistica Slovaca, vol. 13, no. 1, pp. 17-24, 2008.

[17] F. G. Bell, D. C. Entwisle, and M. G. Culshaw, "A geotechnical survey of some British coal measures mudstones, with particular emphasis on durability," Engineering Geology, vol. 46, no. 2, pp. 115-129, 1997.

[18] M. He, L. Zhou, D. Li, C. Wang, and W. Nie, "Experimental research on hydrophilic characteristics of mudstone in deep well," Chinese Journal of Rock Mechanics and Engineering, vol. 27, no. 6, pp. 1113-1120, 2008, in Chinese.

[19] T. Heggheim, M. V. Madland, R. Risnes, and T. Austad, "A chemical induced enhanced weakening of chalk by seawater," Journal of Petroleum Science and Engineering, vol. 46, no. 3, pp. 171-184, 2005.

[20] J. C. Dick and A. Shakoor, "Lithological controls of mudrock durability," Quarterly Journal of Engineering Geology and Hydrogeology, vol. 25, no. 1, pp. 31-46, 1992.

[21] V. G. Moon and A. G. Beattie, "Textural and microstructural influences on the durability of Waikato Coal Measures mudrocks," Quarterly Journal of Engineering Geology and Hydrogeology, vol. 28, no. 3, pp. 303-312, 1995.

[22] C. Gokceoglu, R. Ulusay, and H. Sonmez, "Factors affecting the durability of selected weak and clay bearing rocks from Turkey, with particular emphasis on the influence of the number of drying and wetting cycles," Engineering Geology, vol. 57, pp. 215-237, 2000. 
[23] G. Dhakal, T. Yoneda, M. Kato, and K. Kaneko, "Slake durability and mineralogical properties of some pyroclastic and sedimentary rocks," Engineering Geology, vol. 65, no. 1, pp. 31-45, 2002.

[24] G. R. Lashkaripour and M. Boomeri, "The role of mineralogy on durability of weak rocks," Pakistan Journal of Applied Sciences, vol. 2, no. 6, pp. 698-701, 2002.

[25] H. Gurgenli, "Geomechanical and Weathering Properties of Weak Roof Shales in Coal Mines," Master's Thesis, West Virginia University, Morgantown, WV, USA, 2006.

[26] A. Díaz-Pérez, I. Cortés-Monroy, and J. C. Roegiers, "The role of water/clay interaction in the shale characterization," Journal of Petroleum Science and Engineering, vol. 58, no. 1-2, pp. 83-98, 2007.

[27] Z. A. Erguler and R. Ulusay, "Water-induced variations in mechanical properties of clay-bearing rocks," International Journal of Rock Mechanics and Mining Sciences, vol. 46, no. 2, pp. 355-370, 2009.

[28] J. E. Gillott, "Fabric of Leda clay investigated by optical, electron-optical and X-ray diffraction methods," Engineering Geology, vol. 4, pp. 133-153, 1990.

[29] F. Huppert, "Influence of microfabric on geomechanical behaviour of tertiary finegrained sedimentary rocks from Central North Island, New Zealand," Bulletin of the International Association of Engineering Geology, vol. 38, no. 1, pp. 83-93, 1988.

[30] E. C. Koncagül and P. M. Santi, "Predicting the unconfined compressive strength of the Breathitt shale using slake durability, shore hardness and rock structural properties," International Journal of Rock Mechanics and Mining Sciences, vol. 36, no. 2, pp. 139-153, 1999.

[31] L. Zeng, H.-B. Bian, Z.-N. Shi, and Z.-M. He, "Forming condition of transient saturated zone and its distribution in residual slope under rainfall conditions," Journal of Central South University, vol. 24, no. 8, pp. 1866-1880, 2017.

[32] H. Dong, R. Huang, and Q.-F. Gao, "Rainfall infiltration performance and its relation to mesoscopic structural properties of a gravelly soil slope," Engineering Geology, vol. 230, pp. 1-10, 2017. 